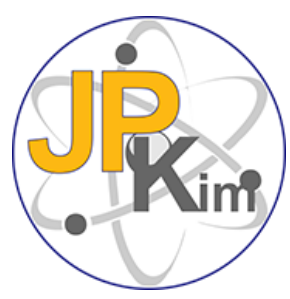

Jurnal Pendidikan Kimia

Vol. 13 | No. 3 |269 - 277| December | 2021

ISSN: 2085-3653| e-ISSN: 2549-3116

https://jurnal.unimed.ac.id/2012/index.php/jpk

https://jurnal.unimed.ac.id

\title{
'Discovery learning model to optimize students' critical thinking skills on hydrocarbon material
}

\author{
Tesa Lonika Yuniawati ${ }^{*}$ and Friska Juliana Purba \\ ${ }^{1}$ Department of Chemistry Education, Faculty of Education, Pelita Harapan University, Tangerang \\ 15811, Indonesia \\ *Corresponding author:TLY, tesalonika237@gmail.com
}

DOI: 10.24114/jpkim.v13i3.30208

Article history:

Received: 29 November 2021

Revised: 07 December 2021

Accepted: 08 December 2021

Abstract: Learning in 21st century requires an advance human mindset, especially critical thinking skills. Critical thinking skills improve the learning process to be more optimal in taking the core of the learning. However, data shows that the critical thinking skills of class XI IPA 2 students are still lacking because they have not been able to answer the analytical questions which is this is the important skills for the students. This paper aims to describe the use of discovery learning models to optimize students' critical thinking skills. The research method used is descriptive qualitative. The research subjects were 28 students of class XI IPA 2 in one of the senior high schools in Jakarta in the academic year 2021/2022 odd semester. Based on the study and data on each indicator, it was found that the use of discovery learning models was able to optimize students' critical thinking skills. Each step in the discovery learning model facilitates the achievement of indicators of critical thinking skills.

Keywords: Critical thinking, discovery learning, learning in 21st century

\section{Introduction}

The life of the 21st century is filled with many developments in knowledge that require all fields including education to improve their quality. To deal with it, the government fixes the curriculum used. The 2013 curriculum is designed to provide meaningful learning through three domains, there are psychomotor, cognitive, and attitude (Silaban, 2021). Aspects of knowledge can be developed through thinking skills, especially critical thinking following the times that require students to have a critical mindset.

Critical thinking which is one of the important goals in education is also part of higherorder thinking skills that must be embedded in students' thinking skills (Adriyanti, 2016; Siahaan et al. 2021). Meanwhile, according to Egok (2016) critical thinking understands the ability to think logically and productively to view conditions, make judgments and make the right decisions. Based on these, critical thinking is a cognitive ability that requires the ability to think to analyze problems in detail and be able to conclude the knowledge obtained. 
Learning can run optimally through the existence of critical thinking skills in students. Rositawati (2018) supports the statement that critical thinking can help students manage their minds to understand the meaning of learning. Overall, critical thinking is the ability of students to reflect, analyze, and find ideas based on their own thoughts (Carter Andrews et al. 2021; Gunawardena \& Wilson, 2021).

Every subject that students learn including chemistry requires critical thinking skills. Chemistry is the study of structure, matter, and energy and their changes (Sugiharti et al. 2019). There are several aspects of learning chemistry, namely symbolic, macroscopic and microscopic. Learning chemistry at the submicroscopic level makes it difficult for students to understand chemistry (Casselman et al. 2021). One of the materials studied by class XI science students in odd semesters is hydrocarbons. Hydrocarbon material is classified as a material with a broad scope. This is supported by Lase \& Purba (2020) that hydrocarbon material has an abstract and broad concept. Students need to understand the concept of this material well to be able to work on hydrocarbon problems that require a lot of analytical skills. In addition, students must remember the type of compound, its structure, and write or describe the compound formula (Dalimunthe, 2017).

Based on the second field experience program at one of the high schools in Jakarta, it was found that students' problems in learning were a lack of critical thinking skills on hydrocarbon material. It was found that some students were not able to answer when the teacher asked questions that required analytical skills, such as the question why gasoline is an organic compound and how to create a compressible structure of a chemical compound. Students are also still less active to answer the questions given so that the teacher needs to appoint them first. When allowed to ask several times, one student asked a question, while the others did not. These facts do not comply with the critical thinking indicators.

According to Ardiyanti (2016), critical thinking indicators can provide simple explanations, conclude, explain further, and determine strategies. Meanwhile, according to Nugraha et al. (2017), namely focusing questions, analyzing opinions, observing, answering, and giving questions, determining the results of opinions, and deciding an action. There are five indicators according to Rositawati (2018), namely analyzing, synthesizing, recognizing, and solving a problem, concluding, and evaluating. Not much different, according to Nurjanah et al. (2019) indicators of critical thinking are interpreting, analyzing, explaining ideas, self-regulation, and concluding.

This paper use four critical thinking indicators. These indicators are answering and asking questions especially with question words why and how analyzing a problem, making conclusions, and explaining ideas to others. These indicators were chosen because they are in accordance with the circumstances and needs of students based on observations that have been made and the indicators are what they want to optimize.

One solution to the problem of students' critical thinking is the discovery learning model (Munthe et al. 2019). According to previous research by Sutoyo \& Priantari (2019), students' critical thinking skills increase with the application of discovery learning because this model is based on constructivism theory, namely students form and find their learning concepts. The discovery learning model is an effective one because it trains higher- order thinking skills and students are more involved or participate in learning (Muttaqiin \& Sopandi, 2016). In connection with these results, this model is appropriate to use because it is in accordance with the needs and conditions of students. During observation, students tend to only get 270

T. L. Yuniawati \& F. J. Purba. Discovery learning model 
information and the teacher only applies questions and answers during learning. However, this has not been able to make students actively involved and understand the material.

The steps of the discovery learning model according to Lieung (2019) are providing stimulus, identifying and hypotheses, discussing, collecting data, concluding, and sharing the findings with others. The Ministry of Education and Culture in Susana (2019) and Sinambela in Yuliana (2018) explain more broadly the steps for implementing discovery learning: stimulation (providing stimulation), the teacher provides problems through questions; in the problem statement, students are allowed to identify the problem; data collection, students are allowed to find sources of information; data processing, processing data that has been obtained by students; verification, proving the statements obtained by students; and generalization, making conclusions. Based on the theory regarding the steps for implementing discovery learning, some steps can be applied by teachers, namely providing stimulus (stimulation), problem statements, data collection, data processing, verification, and generalization.

\section{Methods}

This research was conducted by using a descriptive qualitative method, data was collected through literature review and portfolio documents from the second field experience program. The subjects of the research were 28 students of class XI IPA 2 in one of the high schools in Jakarta in the 2021/2022 academic year, odd semester. The design of activities in this research as presented in Table 1.

Table 1

Design of activities

\begin{tabular}{l|l|l}
\hline No & \multicolumn{1}{|c}{ Date } & \multicolumn{1}{c}{ Activity } \\
\hline 1 & July 28 - August 4 & Problem identification \\
\hline 2 & August 5-25 & Teaching practice \\
\hline 3 & August 26- September 6 & Compilation of portfolio data \\
\hline 4 & September 7-14 & Background preparation and revision \\
\hline 5 & September 15- October 11 & Preparation of theory, discussion and revision \\
\hline
\end{tabular}

Hydrocarbon is the topic of problem identification and were carried out through field observations. The data was collected by analyzing observation sheets, observation reflections, and teaching reflections. Furthermore, this data is used to search for supporting literature on the problem and determine the right solution to the problem. The measurement of success in this study uses predetermined problem indicators.

\section{Results and Discussion}

The discovery learning model can be applied as a solution to overcome the lack of critical thinking skills and make learning oriented to students. Several studies that have applied the discovery learning model confirm a strong correlation that the model can facilitate and encourage students to think critically. In practice, the teacher applies discovery learning three times to the sub-material of nomenclature, physical and chemical properties of 
hydrocarbon compounds with a combination of asynchronous and synchronous time. The steps of the discovery learning model and its implementation in learning in class XI IPA 2 can be seen in Table 2. Based on a series of learning, discovery learning can optimize critical thinking as seen from student responses as presented in the Table 3.

Table 2

The steps of the discovery learning (DL) model in XI IPA 2

\begin{tabular}{l|l}
\hline Steps of Discovery Learning & \multicolumn{1}{c}{ Student Activities } \\
\hline Stimulation & $\begin{array}{l}\text { Students watch and observe learning videos containing } \\
\text { basic concepts }\end{array}$ \\
\hline Problem statement & Students are given questions through practice questions \\
\hline Data collection & $\begin{array}{l}\text { Students collect data or sources to answer questions } \\
\text { together with their groups }\end{array}$ \\
\hline Verification & Students share their opinions or answers in groups \\
\hline $\begin{array}{l}\text { Students are given time to ask questions while the teacher } \\
\text { emphasizes important points } \\
\text { Discuss the results of student work with the teacher during } \\
\text { a synchronous session and relate it to the material that has } \\
\text { been studied (synchronous) and provide feedback on } \\
\text { asynchronous student worksheets }\end{array}$ \\
\hline Generalization & Students conclude at the end of the lesson \\
\hline
\end{tabular}

Based on the results in the table, the discovery learning model can optimize students' critical thinking skills. The first step, namely stimulation, aims to provide stimulation and arouse students' curiosity. At this step, the critical thinking indicator that is honed is to ask questions. The teacher's role is to provide a stimulus in the form of a learning video containing basic material to be studied in an asynchronous session. Students' responses after watching were some students asked questions as described in table three number one in the synchronous session. This shows students think critically to be able to ask questions. For example, when students watch videos of alkenes and alkynes, students ask whether it is possible if both are in a compound and how to name them.

The second learning step is the problem statement. The teacher gives problems in the form of questions that must be solved by students. After the students' thinking abilities have been stimulated from the stimulation stage, problems are given to further hone their cognitive abilities. Critical thinking indicators that can be optimized at this stage are analyzing a problem. After the problem is given, students discuss it in groups through the channel in Microsoft Teams to identify the questions they need to solve. Students actively discuss to understand the given problem such as observing the naming, observing the graph, and paying attention to the reactants given. After that, students will have a hypothesis of the problem they must solve.

Data collection is the third step of discovery learning. At this step, the teacher plays a role in guiding students by ensuring that the sources that students collect are appropriate. As a result, students collect relevant sources such as personal notes, teacher learning videos, and other sources from the internet to answer the questions. Critical thinking indicators that can be achieved from this activity are answering questions, asking questions, conveying ideas to others, and analyzing problems. To be able to obtain the right sources, 
students need to analyze the questions and match them according to the sources obtained. After that, students ask each other and answer whether the sources they can help to solve the problem.

Table 3

Indicators, results, and evidence of the application of the discovery learning model

\begin{tabular}{|c|c|}
\hline Indicators of critical thinking & Result \\
\hline $\begin{array}{l}\text { Answering and asking questions, } \\
\text { especially with question words } \\
\text { why and how }\end{array}$ & 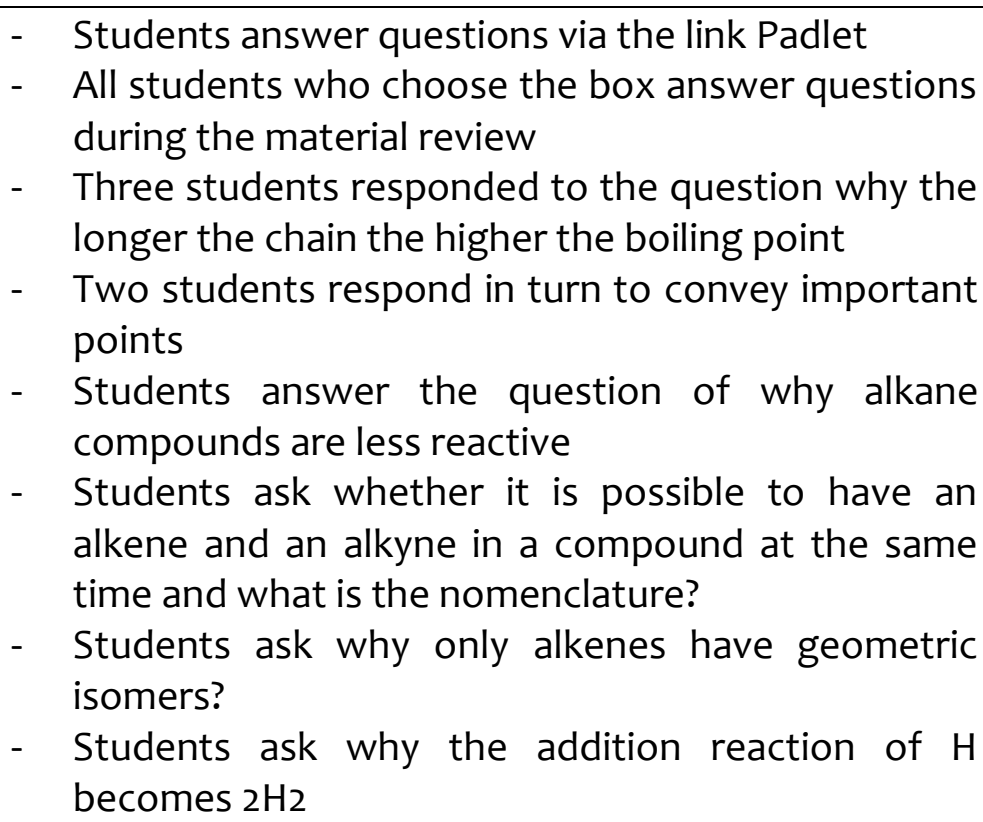 \\
\hline Analyzing a problem & $\begin{array}{l}\text { - Four of the six groups answered the question of } \\
\text { analyzing whether the naming of the given } \\
\text { compound was correct or not and corrected if it } \\
\text { turned out that the naming was clearly and } \\
\text { correctly } \\
\text { - All (six) groups can answer the isomer analysis } \\
\text { questions and physical properties presented in the } \\
\text { graph correctly } \\
\text { All (six) groups can answer the questions to } \\
\text { interpret the reaction results }\end{array}$ \\
\hline Make conclusion & $\begin{array}{l}\text { - Students get conclusions from the results of the } \\
\text { discussion }\end{array}$ \\
\hline Explaining ideas to others & $\begin{array}{ll}\text { - } & \text { Students actively discuss, share opinions, help and } \\
\text { explain each other } \\
\text { - } & \text { Students share their opinions with each other } \\
\text { - } & \text { Students discuss with their friends in a group }\end{array}$ \\
\hline
\end{tabular}

The fourth step of discovery learning is data processing. The students in their groups process the information that has been collected and match it with the source. After that, the teacher will make sure their work is correct. Data processing can optimize several critical thinking indicators including conveying ideas to others, analyzing problems, answering questions, and asking questions. This is supported by Alfi et al. (2016) which stated that 
when students find information correctly from sources, students use their critical thinking skills.

Fig 1, is one of the questions that must be solved by students. Students were asked to determine several compounds based on isomers and boiling points on the graph. During the discussion, students obtained sources of information on how to determine isomers and boiling points of hydrocarbon compounds. The results of student work are all correct, which means students used their critical thinking skills. It is safe to say that students used their critical thinking skills because of several reason. First of all, the students were able to make three isomers of the $\mathrm{C}_{5} \mathrm{H}_{12}$ compound. Students analyze the isomeric structure by looking at the longest chain and paying attention to the branches. Secondly, students analyzed the boiling point graph by applying the concepts they got from the source and matching each isomer with the boiling point of hydrocarbon compounds. Lastly, students got answers from the compounds they have to determine.

The following is a graph of the boiling points of 3 isomers of the compound $\mathrm{C}_{3} \mathrm{H}_{12}$

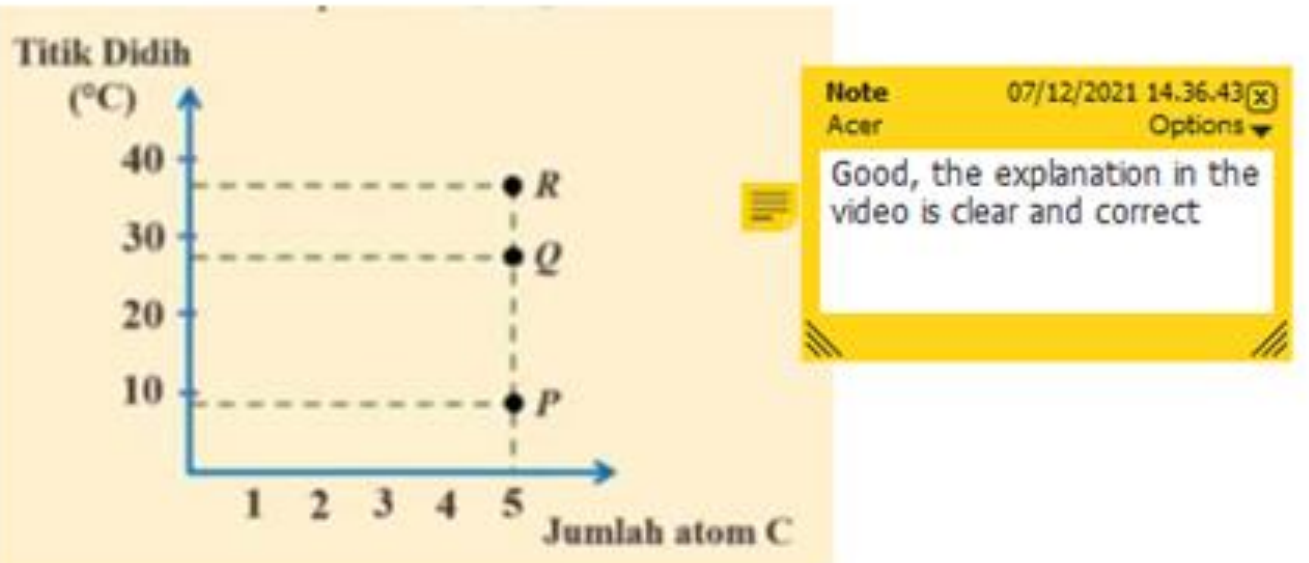

Based on the graph, it can be predicted that the predictions of $\mathrm{P}, \mathrm{Q}$ and $\mathrm{R}$ are...

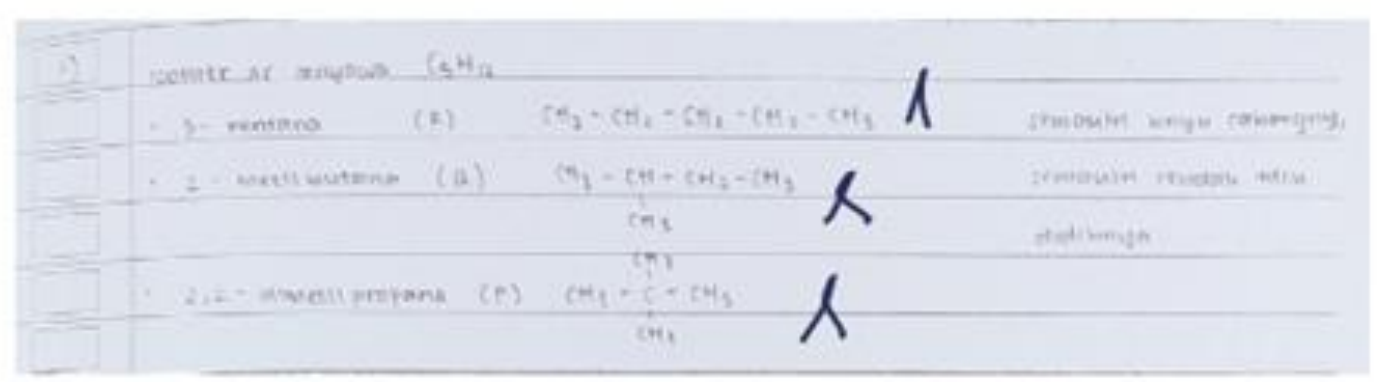

Fig 1. Problems with isomerism and physical properties along with student answers

The fifth step of the discovery model is verification. This step is done in a synchronous session with the teacher. The teacher asked group representatives to submit their answers and as a result, each group representative conveys the results of the data processing step. The teacher plays a role in checking and ensuring the correctness of the answers obtained by each group. These are in line with efforts to optimize students' critical thinking skills, especially on the indicators of conveying answers and conveying ideas to others. Fellow 
students will complement each other's answers and the teacher will also verify the results of their discussions to have a complete understanding. At this stage, some students ask appropriate questions to clarify some unclear things. The teacher also conveys important points from the material and the results of the discussion.

The last learning step is generalization. At this step, the teacher and student representatives conclude the lesson. The teacher provides opportunities for students to convey conclusions based on discussions and discussions with the teacher. Pohan et al. (2021) stated that by concluding, students increasingly gain a more complete understanding. The critical thinking indicators achieved in this step are concluding and conveying ideas to others. The students responds that they can conclude, but it is not seen significantly. This can happen because in two out of three online learning sessions which are identical to time constraints, the teacher does not have enough time to conclude the lesson. Teachers need to manage time better, considering the weakness of discovery learning itself takes quite a long time.

Critical thinking skills have a positive effect on student scores. Kurniawan et al. (2020) confirmed this, if students have critical thinking skills, they tend to have good learning outcomes as well (Sibuea et al. 2019). The existence of problems which must be solved by students with their critical thinking skills also arouses students' curiosity and interest in learning and students have time to convey the results of their discussions (Youllanda et al. 2021). Students are better trained to solve existing problems. The formative results were obtained results from 26 students (92.86\%) students obtained formative results above the KKM limit of 75. Formative questions include the nomenclature of alkanes, alkenes, and alkynes. Based on the results of students, students can analyzed and distinguished the three hydrocarbon groups. Through this, students are responsible for maximizing their thinking abilities which have been given by God.

Critical thinking skills are important for students, especially in everyday life to solve problems appropriately (Siahaan et al. 2021). When students find a problem, students should not just standstill. Students need to realize they have the ability to think and take responsibility for the problems they face. Students must take the initiative to use critical thinking skills to find causes and find the right solution or solution to the problems they face.

\section{Conclusion}

The discovery learning model can optimize students' critical thinking skills on hydrocarbon material. This is achieved through the steps of the discovery learning model. This stage begins by providing learning videos in the stimulation stage, providing problems at the problem statement stage, guiding students at the data collection stage, data processing, verification, to generalization. All stages involve students to actively solve problems in the form of questions. At each of these stages, there are indicators of critical thinking which are increasingly optimal as seen from student responses and the way students conveying ideas to others. The student responds that they can conclude, but it is not seen significantly. This can happen because in two out of three online learning sessions which are identical to time constraints, the teacher does not have enough time to conclude the lesson. Teachers need to manage time better, considering the weakness of discovery learning itself takes quite a long time. 


\section{References}

Ardiyanti, Y. (2016). Berpikir kritis siswa dalam pembelajaran berbasis masalah berbantuan kunci determinasi. Jurnal Pendidikan Indonesia, 5(2), 193-202. DOI:10.23887/jpiundiksha.v5i2.8544

Casselman, M. D., Eichler, J. F., \& Atit, K. (2021). Advancing multimedia learning for science: Comparing the effect of virtual versus physical models on student learning about stereochemistry. Science Education, 105(6), 1285-1314. DOl:10.1002/sce.21675

Carter Andrews, D. J., Richmond, G., \& Marciano, J. E. (2021). The teacher support imperative: Teacher education and the pedagogy of connection. Journal of Teacher Education, 72(3), 267-270. DOI:10.1177/00224871211005950

Dalimunthe, M. (2017). The differences in student learning outcomes by using the jigsaw type cooperative method and the recitation method on hydrocarbon material. Jurnal Pendidikan Kimia, 9(3), 336-340. DOl:10.24114/jpkim.v9i3.8383

Egok, A. S. (2016). Kemampuan berpikir kritis dan kemandirian belajar dengan hasil belajar matematika. Jurnal Pendidikan Dasar, 7, 185-198. DOI:10.21009/JPD.072.01

Gunawardena, M., \& Wilson, K. (2021). Scaffolding students' critical thinking: A process not an end game. Thinking Skills and Creativity, 41, 100848. DOl:10.1016/j.tsc.2021.100848

Kurniawan, T. D., Kuswanto, Utami, W., \& Wardhana, I. (2020). Science process skills and critical thinking in science urban and rural disparity. Jurnal Pendidikan IPA Indonesia, 9(4), 489-498. DOI:10.15294/jpii.v9i4.24139

Lase, E. K., \& Purba, F. J. (2020). Upaya meningkatkan hasil belajar kognitif kimia siswa dengan menggunakan metode latihan (drill). SAP (Susunan Artikel Pendidikan), 5(1), 1825. DOl:10.30998/sap.v5i1.6501

Lieung, K. W. (2019). Pengaruh model discovery learning terhadap kemampuan berpikir kritis siswa sekolah dasar. Journal of Primary Education, 2(1), 73-82. DOl:10.35724/musjpe.v1i2.1465

Munthe, E. A., Silaban, S., \& Muchtar, Z. (2019). Discovery learning based e-module on protein material development. Advances in Social Science, Education and Humanities Research, 384, 604-607.

Muttaqiin, A., \& Sopandi, W. (2016). Pengaruh model discovery learning dengan sisipan membaca kritis terhadap kemampuan berpikir kritis siswa. EDUSAINS, 57-65. DOl:10.15408/es.v8i1.1752

Nugraha, A. J., Suyitno, H., \& Susilaningsih, E. (2017). Analisis kemampuan berpikir kritis ditinjau dari keterampilan proses sains dan motivasi belajar melalui model PBL. Journal of Primary Education, 6(1), 35-43. DOl:10.15294/JPE.V6I1.14511

Nurjanah, R. R., Rinanto, Y., \& Prayitno, B. A. (2019). Pengaruh model pembelajaran discovery learning terhadap kemampuan berpikir kritis pada materi virus kelas X SMA negeri 8 Surakarta tahun pelajaran 2018/2019. Bioedukasi: Jurnal Pendidikan Biologi, 12(2), 195-201. DOI: 10.20961/bioedukasi-uns.v12i2.27586

Pohan, A. E., Yulia, D., \& Husna, A. (2021). Micro teaching berbasis pendekatan ilmiah. Indramayu: Penerbit Adab.

Rositawati, D. N. (2018). Kajian berpikir kritis pada metode inkuiri. Prosiding Seminar Nasional Fisika dan Aplikasinya, 74-84. DOl:10.20961/prosidingsnfa.v3io.28514 
Siahaan, R., Sitorus, M., \& Silaban, S. (2021). The development of teaching materials oriented to critical thinking skills for chemistry class XI high school. Jurnal Pendidikan Kimia, 13(1), 60-68. DOI:10.24114/jpkim.v13i1.24145

Sibuea, G. V., Suyanti, R. D., \& Silaban, S. (2019). The development of chemistry lab guide book for high school based on guided inquiry to measure scientific attitudes and science process skill. In Proceedings International Seminar on Transformative Education and Educational Leadership, 319-325.

Silaban, S. (2021). Pengembangan program pengajaran. Medan: Yayasan Kita Menulis.

Sugiharti, G., Hamid, A., \& Mukhtar, M. (2019). The implementation of learning model and virtual lab toward learning outcome of chemistry education. Jurnal Pendidikan Kimia, 11(3), 79-86. DOI:10.24114/jpkim.v11i3.15734

Susana, A. (2019). Pembelajaran discovery learning menggunakan multimedia aktif. Bandung: Tata Akbar.

Sutoyo, \& Priantari, I. (2019). Discovery learning meningkatkan kemampuan berpikir kritis siswa. BIOMA: Jurnal Biologi dan Pembelajaran Biologi, 4(1), 31-45. DOI:10.32528/bioma.v4i1.2649

Youllanda, W., Medriarti, R., \& Swistoro, E. (2021). Hubungan antara kemampuan berpikir kritis dengan hasil belajar melalui model inkuiri terbimbing. Jurnal Kumparan Fisika, 3(3), 191-198. DOI:10.33369/jkf.3.3.191-198

Yuliana, N. (2018). Penggunaan model pembelajaran discovery learning dalam peningkatan hasil belajar siswa di sekolah dasar. Jurnal Ilmiah Pendidikan dan Pembelajaran, 2(1), 21-28. DOI:10.23887/jipp.v2i1.13851 